\title{
Biodegradation of n-hexadecane by bacterial strains B1 and B2 isolated from petroleum-contaminated soil
}

\author{
LIU Tao ${ }^{1,2,3}$, WANG FengHua ${ }^{3,4}$, GUO LanPing ${ }^{5}$, LI XiaoLiang ${ }^{6}$, \\ YANG XiaoJin ${ }^{3} \&$ LIN Ai Jun ${ }^{3 *}$ \\ ${ }^{1}$ State Key Laboratory of Pollution Control and Resource Reuse (Tongji University), Shanghai 200092, China \\ ${ }^{2}$ Experimental Teaching Center of Environmental Science and Engineering, Tongji University, Shanghai 200092, China \\ ${ }^{3}$ Department of Environmental Science and Engineering, Beijing University of Chemical Technology, Beijing 100029, China \\ ${ }^{4}$ Department of Soil Environmental Sciences, Research Center for Eco-Environmental Sciences, Chinese Academy of Sciences, \\ Beijing 100085, China \\ ${ }^{5}$ Institute of Chinese Material Medical, China Academy of Chinese Medical Sciences, Beijing 100700, China \\ ${ }^{6}$ Chinese Academy for Environmental Planning, Beijing 100012, China
}

Received September 23, 2011; accepted November 17, 2011; published online June 7, 2012

\begin{abstract}
Two hydrocarbon-biodegrading bacterial strains, B1 and B2, were isolated from petroleum-contaminated soil collected from Tianjin, China. The strains were identified as Pseudomonas aeruginosa (B1) and Acinetobacter junii (B2). The degradation rate of $\mathrm{n}$-hexadecane by $\mathrm{B} 1$ and $\mathrm{B} 2$ reached $96 \%$ and $78 \%$ respectively after 7 days, though the strains employed different mechanisms of degradation. The results showed that B2 was not able to use glucose as carbon source. B1 could produce glycolipid surfactants using glucose as the carbon source, according to the results of blue agar plate analysis and thin layer chromatography (TLC), and the bacterial culture of B1 had a high oil discharge and emulsification activity. Both B1 and B2 could produce biosurfactants with hexadecane as the sole carbon source, but their modes of action were different. The carbon source was found to affect the cell surface hydrophobicity. Cell surface hydrophobicity was poor with glucose as the carbon source, but enhanced when hexadecane was used as the carbon source.
\end{abstract}

hexadecane, biosurfactant, hydrophobicity, emulsification, bacteria

\section{Introduction}

Petroleum, which is widely used in everyday life, is one of the most important energy sources for industry and transport. However, hydrocarbon pollutants (such as oils) released by the extraction, processing and use of petroleum accumulate frequently in soil, marine, groundwater, and other aqueous environments, threatening the ecosystem [1-3]. The insoluble characteristics of hydrocarbons make their clean-up extremely difficult. Conventional physical and chemical approaches to the remediation of hydrocarbons are usually expensive and laborious, and require the use of hazardous

*Corresponding author (email: ajlin@126.com) solvents, which can lead to secondary environmental pollution $[4,5]$. Conversely, the bioremediation of soils contaminated by petroleum has been shown to be an efficient, economical, versatile, and environmentally friendly way of mopping up hydrocarbon pollutants [4-6].

Despite the highly efficient hydrocarbon-degrading properties of some bacterial strains, one of the key limiting steps in bioremediation is the inadequate bioavailability of hydrocarbons to microorganisms due to their low solubility, which limits the uptake of hydrocarbons by various organisms [7-10]. Uptake and use of water-insoluble substrates by organisms requires specific physiological adaptations, and various strategies had been developed by different bacteria to interact with these hydrophobic compounds. Two 
general types of hydrocarbon-cell interactions have been postulated, depending on the state and size of the oil droplets relative to the size of microbial cells: specific adhesion of cells to larger oil drops, and pseudo-solubilization involving the cellular assimilation of emulsified smaller hydrocarbon droplets [11]. Most hydrocarbon-degrading bacteria excrete biosurfactants, amphiphilic molecules of diverse chemical nature, which improves the ability of microbial cells to use hydrophobic compounds as growth substrates $[12,13]$. Surfactants not only affect substrates, increasing or in some cases decreasing their bioavailability [14-16], but also have an impact on microbial cells, evoking changes in their hydrophobicity and surface charge matrices [17]. Zhang and Miller [18] found that surfactant bound to bacteria changed the surface cell hydrophobicity and thus altered cells' affinity to the hydrophobic substrate, increasing uptake and biodegradation.

Hexadecane is present in the aliphatic fraction of crude oil and is one of the major components of diesel [19]. Due to its presence at many oil-contaminated sites and its well-characterized biodegradability [20], this compound has been used as a model molecule to study aliphatic hydrocarbon biodegradation [21]. In the present study, two bacterial strains, B1 and B2, were isolated from petroleum-contaminated soil from Tianjin, China, and characterized as Pseudomonas aeruginosa (B1) and Acinetobacter junii (B2). Both were able to use hydrocarbons as the carbon and energy source and produce biosurfactants when grown on hydrocarbons and other water-miscible and immiscible carbon substrates. Despite numerous reports of isolated strains which can produce biosurfactants and have high degradation ability, most studies have looked at only one kind of strain. This study investigated and compared the different mechanisms of hydrocarbon degradation by two bacterial strains, B1 and B2, including the role of biosurfactants and the relationship between cell surface hydrophobicity and the ability of such bacteria to degrade hydrocarbons.

\section{Material and methods}

\subsection{Bacterial isolation and culture conditions}

Two bacteria named B1 and B2 were used in this study. These two strains were isolated from soil collected from petroleum-contaminated sites in Tianjin, China by enrichment culture, and were found to exhibit a relatively strong potential to biodegrade petroleum hydrocarbons. Both strains could grow in a $100 \mathrm{~mL}$ Erlenmeyer flask containing $40 \mathrm{~mL}$ of mineral salt medium (MSM) with $5,000 \mathrm{mg} / \mathrm{L}$ hexadecane as the carbon source.

Culture mediums were sterilized in an autoclave at $121^{\circ} \mathrm{C}$ for $20 \mathrm{~min}$. The mineral salt medium contained $0.05 \% \mathrm{KH}_{2} \mathrm{PO}_{4}, 0.05 \% \mathrm{~K}_{2} \mathrm{HPO}_{4}, 0.3 \% \mathrm{NH}_{4} \mathrm{NO}_{3}$, and $0.2 \%$ $(\mathrm{V} / \mathrm{V})$ trace elements solution. The trace elements solution contained $0.4 \% \mathrm{MgSO}_{4}, 0.1 \% \mathrm{FeSO}_{4}, 0.1 \% \mathrm{CuSO}_{4}, 0.1 \%$
$\mathrm{CaCl}_{2}$, and $0.1 \% \mathrm{MnSO}_{4}$. The $\mathrm{pH}$ value was adjusted to 7.0-7.2 using $0.1 \mathrm{~mol} / \mathrm{L} \mathrm{NaOH}$ or $0.1 \mathrm{~mol} / \mathrm{L} \mathrm{HCl}$. Flasks containing culture media were incubated at $30^{\circ} \mathrm{C}$ on a rotary shaker $(150 \mathrm{r} / \mathrm{min})$ for 4 days. At the end of the incubation period, $1.0 \mathrm{~mL}$ of the enriched culture was transferred to a fresh medium containing $5,000 \mathrm{mg} / \mathrm{L}$ hexadecane and re-incubated for another 4 days.

\subsection{Identification of bacteria}

The bacteria were identified by determining the gene sequence coding for $16 \mathrm{~S}$ ribosomal DNA (16S rDNA). A modification of the sodium dodecyl sulfate (SDS)-based extraction method was used to obtain genomic DNA from the Luria-Bertani (LB) culture. The extracted DNA was stored at $-20^{\circ} \mathrm{C}$ for later use in polymerase chain reaction (PCR). PCR was performed on the extracted DNA to amplify the $16 \mathrm{~S}$ rDNA genes. The forward primer of $27 \mathrm{~F}$ (5'-AGAGTTTGATCATGGCTCAG-3', universal primer) and the reverse primer of 1492R (5'-TACGGTTACCTT GTTACGACTT-3', universal primer) were used for the PCR. The PCR mixture contained $5.0 \mu \mathrm{L}$ buffer, $4 \mu \mathrm{L}$ deoxynucleoside triphosphate (dNTP), $1.0 \mu \mathrm{L}$ each of forward primer $(27 \mathrm{~F})$ and reverse primer $(1492 \mathrm{R}), 1.0 \mu \mathrm{L}$ of DNA template, and $0.25 \mu \mathrm{L}$ of Taq DNA polymerase in a final volume of $50 \mu \mathrm{L}$. Amplification was performed using an automated thermal cycler. PCR amplification was carried out under the following conditions: initial denaturation at $95{ }^{\circ} \mathrm{C}$ for $5 \mathrm{~min}$; 30 cycles of denaturation for $1 \mathrm{~min}$ at $95^{\circ} \mathrm{C}$, annealing for $2 \mathrm{~min}$ at $52^{\circ} \mathrm{C}$, extension for $2 \mathrm{~min}$ at $72{ }^{\circ} \mathrm{C}$ respectively, and a final extension at $72{ }^{\circ} \mathrm{C}$ for $10 \mathrm{~min}$. The PCR products were separated by electrophoresis using $0.1 \%$ agarose gel in TAE buffer. To identify the isolated bacteria, the 16S rDNA consensus sequence obtained from Shanghai Sangon Biological Engineering Technology \& Services Company Limited was then compared with $16 \mathrm{~S}$ rDNA gene sequences from the public GenBank (US), EMBL (Europe), and DDBJ (Japan) databases using the advanced gapped n-BLAST program, version 2.1. The program was run via the Internet through the National Center for Biotechnology Information website (http://www.ncbi. nlm.nih.gov/blast/). Sequences found to be more than $98 \%$ identical to a GenBank sequence were considered to be the same species as the highest score-matching sequence on the public databases.

\subsection{Hexadecane and extracellular fatty acid analysis}

\subsubsection{Hexadecane analysis}

Residual hexadecane in the culture medium was extracted three times with an equal volume of hexane as the extraction solvent. The quantity of hexadecane in the extract was determined using a gas chromatograph with a flame ionization detector (GC-FID, Agilent 6820, USA). The GC-FID was operated with nitrogen as the carrier gas at a flow rate 
of $5.0 \mathrm{~mL} / \mathrm{min}$, inlet temperature of $250{ }^{\circ} \mathrm{C}$, detector temperature of $300{ }^{\circ} \mathrm{C}$, and an oven temperature program rising from $100{ }^{\circ} \mathrm{C}$ (held for $2 \mathrm{~min}$ ) to $300{ }^{\circ} \mathrm{C}$ (held for $10 \mathrm{~min}$ ) at a rate of $10{ }^{\circ} \mathrm{C} / \mathrm{min}$. The injection volume for all samples was $1 \mu \mathrm{L}$.

\subsubsection{Extracellular fatty acid analysis}

The growth culture medium $(5 \mathrm{~mL})$ was subjected to liquid-liquid extraction following basification to $\mathrm{pH}>11$ using $0.1 \mathrm{~mol} / \mathrm{L} \mathrm{NaOH}$ solution, then extracted using $10 \mathrm{~mL}$ dichloromethane $\left(\mathrm{CH}_{2} \mathrm{Cl}_{2}\right)$ three times. The remnant aqueous phase was acidified to $\mathrm{pH}<2$ using $\mathrm{HCl}$ and extracted using

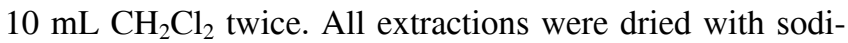
um sulphate and concentrated by nitrogen blowing. The fatty acid fraction of the extract was analyzed using gas chromatography-mass spectrometry (GC-MS) (Agilent GC/MS, GC 7890A, MSD 5975C). The mass spectrometry conditions were as follows: ion source, $250{ }^{\circ} \mathrm{C}, 1200 \mathrm{~V}$; scanning mode, completely scan 35-500 amu. The conditions for $\mathrm{GC}$ were as follows: the temperature program rose from 60 to $280{ }^{\circ} \mathrm{C}$ (held for $5 \mathrm{~min}$ ) at a rate of $10{ }^{\circ} \mathrm{C} / \mathrm{min}$, while the inlet temperature was $280{ }^{\circ} \mathrm{C}$, and nitrogen gas was the carrier gas at a flow rate of $25 \mathrm{~mL} / \mathrm{min}$. The injection volume for all samples was $1 \mu \mathrm{L}$.

\subsection{Physicochemical characterization of biosurfactant produced by $B 1$ and $B 2$}

\subsubsection{Oil displacement test}

The oil displacement test was done using the method described by Rodrigues et al. [22] with some amendments. Firstly, $50 \mathrm{~mL}$ of redistilled water was added to a Petri dish with a diameter of $15 \mathrm{~cm}$. Then, $30 \mu \mathrm{L}$ of hexadecane was pipetted into the dish to form a thin oil layer on the surface of the water, followed by $100 \mu \mathrm{L}$ of bacterial culture solution deposited onto the surface of the oil making a clear zone in the center of the oil layer. The maximum diameter of the clear zone was recorded under daylight. The higher the surface activity of the test solution, the larger the diameter of the clear zone [23].

\subsubsection{Measurement of emulsification activity}

Emulsification activity was determined according to the method described by Cooper and Goldenberg [24] with some modifications. A mixture of $3 \mathrm{~mL}$ of the studied hexadecane or diesel oil and $2 \mathrm{~mL}$ of bacterial culture solution was vortexed at high speed for $2 \mathrm{~min}$. The emulsification activity was determined after $24 \mathrm{~h}$ and the emulsification index $\left(E_{24}\right)$ was calculated using the following equation: $E_{24}(\%)=$

\footnotetext{
Height of emulsified zone

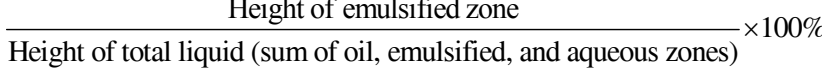

The higher the emulsification index $\left(E_{24}\right)$, the higher the emulsification activity of the tested surfactant.
}

\subsubsection{Blue agar culture analysis}

Extracellular glycolipid production was detected by blue agar culture analysis according to the method described by Siegmund et al. [25]. After 3 days incubation in a $30{ }^{\circ} \mathrm{C}$ rotary shaker, the culture solution was plated onto blue agar plates, and the blue agar plates were incubated at $30{ }^{\circ} \mathrm{C}$ for 2-3 days in the dark. The plates contained $0.5 \%$ cetyltrimethylammonium bromide (CTAB), $0.002 \%$ methylene blue, $0.5 \%$ beef extract, $1.0 \%$ peptone, $0.5 \%$ sodium chloride $(\mathrm{NaCl})$, and $2.0 \%$ agar. Biosurfactant production could be observed by the formation of dark blue halos around the colonies.

\subsubsection{Analysis of cell surface hydrophobicity}

The microbial adherence to hydrocarbons (MATH) assay was used to test the hydrophobicity of the strains. The general protocol of MATH is described by Zhang and Miller [18] in detail. In this experiment, cells were washed with MSM three times from the cell pellet, then resuspended in MSM and adjusted to an optical density measured at a wavelength of $600 \mathrm{~nm}\left(\mathrm{OD}_{600}\right)$ of 0.4-0.6. Diesel oil (5 mL) was added to $5 \mathrm{~mL}$ of the adjusted cell suspension in a test tube and was vortexed for $5 \mathrm{~min}$. After that, the mixture was allowed to settle and separate for $5 \mathrm{~min}$, and then the $\mathrm{OD}_{600}$ of the aqueous phase was measured. The MATH value was calculated according to the following equation.

$\% \mathrm{MATH}=$

$\left[1-\frac{\mathrm{OD}_{600} \text { of aqueous phase of culture after the addition of diesel oil }}{\mathrm{OD}_{600} \text { of culture before the addition of diesel oil }}\right] \times 100 \%$

\section{Production and purification of biosurfactant}

To investigate the production and activity of biosurfactant produced by the strains in different mediums, the strains were grown on MSM containing only water-soluble (glucose) or insoluble (hexadecane) carbon sources, or a mixture of glucose and hexadecane, at $30^{\circ} \mathrm{C}$ on a rotary shaker (150 r/min) for 7 days.

After bacterial cells were removed by centrifugation at $3,700 \mathrm{r} / \mathrm{min}$ for $30 \mathrm{~min}$ at $4^{\circ} \mathrm{C}$, the supernatant was acidified to $\mathrm{pH} 2.0$ using $1 \mathrm{~mol} / \mathrm{L} \mathrm{HCl}$, and the acidified supernatant was left overnight at $4{ }^{\circ} \mathrm{C}$ for complete precipitation of the biosurfactant. For purification of surface-active component(s), the supernatant was extracted with an equal volume of solvent made up of chloroform: methanol $(2: 1, \mathrm{~V} / \mathrm{V})$ [26]. The organic solvent was transferred to a round-bottom flask connected to a rotary evaporator to remove the solvent, and the residual material was considered to be crude biosurfactant. The crude product was dissolved in dichloromethane and after being filtered to remove any coarse material, the solvent was removed with the aid of rotary evaporator and the solid was washed with triplicate volumes of hexane to remove alkenes and free fatty acids. Hexane was then evaporated and the resulting material was considered to be puri- 
fied biosurfactant.

The purified extract was dissolved in dichloromethane and analyzed by thin layer chromatography (TLC) on silica gel plates. The samples were separated on silica gel plates using chloroform: methanol: distilled water $(65: 25: 4, V / V / V)$ as the solvent system. The components were detected by spraying the plate with ninhydrine reagent for lipopeptide and anthrone reagent for glycolipide detection respectively [27].

\section{Results}

\subsection{Characterization of bacterial strains B1 and B2}

The PCR products were separated by electrophoresis using $0.1 \%$ agarose gel in TAE buffer (Figure 1). Taxonomical identification of these two strains, designated B1 and B2, was performed by amplifying and sequencing the $16 \mathrm{~S}$ rDNA genes and comparing them to the database of known $16 \mathrm{~S}$ rDNA sequences. Alignment of the $16 \mathrm{~S}$ rDNA gene sequences of B1 and B2 with sequences obtained by doing a blast search revealed $99 \%$ similarity to Pseudomonas aeruginosa and $98 \%$ similarity to Acinetobacter junii respectively. Thus, the two strains were designated as Pseudomonas sp. (B1) and Acinetobacter sp. (B2).

\subsection{Hexadecane and extracellular fatty acid analysis}

After 7 days, biodegradation of $500 \mathrm{mg} / \mathrm{L}$ hexadecane by bacterial strains B1 and B2 was around $96 \%$ and $78 \%$, respectively; an increase in bacterial growth was concomitant with a decrease in hexadecane concentration. During the growth of B1 and B2 with addition of n-hexadecane, the $\mathrm{pH}$ of the bacterial culture decreased from 6.8 to 4.8 and 4.3 respectively (Figure 2 ). This change in culture medium $\mathrm{pH}$ may have been induced by fatty acid generation from the degradation of hexadecane. After extraction, the ectocytic fatty acid content was determined using GC-MS. Strain B1

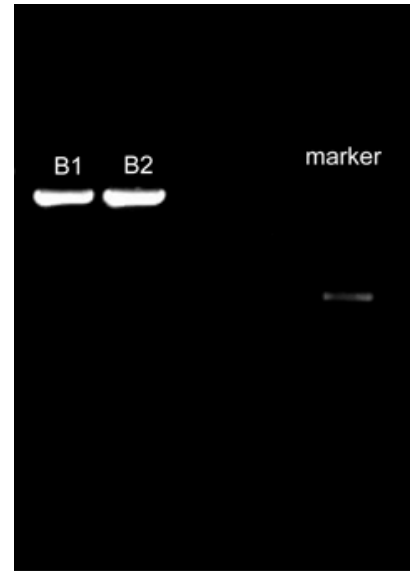

Figure 1 The picture of $1 \%$ agarose gel electrophoresis of PCR products.

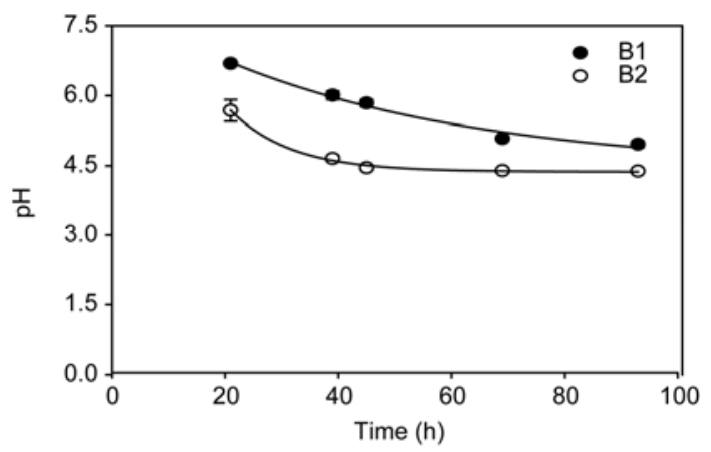

Figure 2 The change of $\mathrm{pH}$ during of the growth of bacteria.

was found to produce 2,3-dihydroxystearic acid $\left(\mathrm{C}_{18} \mathrm{H}_{38} \mathrm{O}_{4}\right)$, hexadecanoic acid $\left(\mathrm{C}_{16} \mathrm{H}_{32} \mathrm{O}_{2}\right)$, propanoic acid $\left(\mathrm{C}_{13} \mathrm{H}_{19} \mathrm{NO}_{2}\right)$, dodecanoic acid $\left(\mathrm{C}_{12} \mathrm{H}_{24} \mathrm{O}_{3}\right)$, quinaldic acid $\left(\mathrm{C}_{10} \mathrm{H}_{9} \mathrm{NO}_{4}\right)$, and so on when grown on hexadecane (Figure 3). Other low molecular weight fatty acids identified included nonenoic acid $\left(\mathrm{C}_{6} \mathrm{H}_{10} \mathrm{O}_{2}\right)$, pentanoic acid $\left(\mathrm{C}_{5} \mathrm{H}_{10} \mathrm{O}_{2}\right)$, and butyric acid $\left(\mathrm{C}_{4} \mathrm{H}_{9} \mathrm{NO}_{3}\right)$. Similar products were detected in the culture solution of B2. The decrease in the $\mathrm{pH}$ of the culture solu-

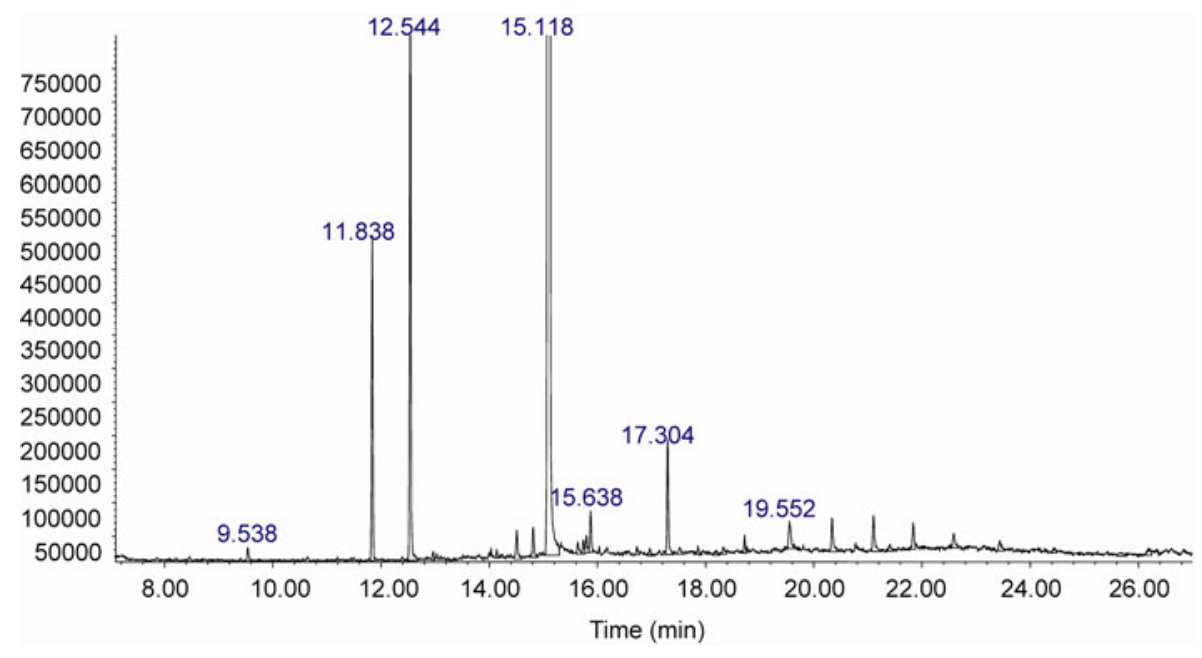

Figure 3 The GC-MS chromatogram of B1'ectocytic fatty acid. 
tion may have been the result of the acids produced.

\subsection{Physicochemical characterization of the biosurfac- tant produced by $B 1$ and $B 2$}

\subsubsection{Oil displacement test and emulsification activity determination}

The results of the oil displacement test and emulsification activity $\left(E_{24)}\right.$ determination are shown in Table 1 . When B1 was grown on glucose, we measured the largest diameter of the clean zone (about $10.2 \mathrm{~cm}$ ), and the highest $\mathrm{E}_{24}$, up to $60 \%$ (hexadecane) and 71\% (diesel oil) respectively. When B1 was grown on a dual carbon source (glucose and hexadecane), the diameter of the clean zone was about $4.5 \mathrm{~cm}$ and $E_{24}$ measured about $18 \%$ (hexadecane) and $20 \%$ (diesel oil) respectively. However, when B1 was grown on hexadecane, the diameter of the clean zone was only $4.1 \mathrm{~cm}$ and the $E_{24}$ was only $6.7 \%$ (hexadecane) and $8.0 \%$ (diesel oil) respectively. B2 did not grow on glucose, but showed similar results of a larger diameter of clean zone and higher emulsification activity when grown on a dual carbon source rather than on hexadecane alone.

The culture solution of B1 mixed with glucose was effective in emulsifying other hydrocarbons, which indicated that the emulsification activity of the test solution was not substrate-specific. Although both strains grew well on hexadecane, they showed low emulsifying activity, especially for B2. Thus, the level of emulsifying activity is related to the carbon source.

\subsubsection{Blue agar culture analysis}

The formation of blue halos around the colonies on the blue agar plate indicated the production of glycolipid biosurfactant. In this study, the formation of dark blue halos around colonies was observed only on the blue agar plate hosting the B1 strain (Figure 4), which indicated that B1 could produce extracellular glycolipid biosurfactant, while B2 could not.

\subsubsection{Analysis of cell surface hydrophobicity}

The results obtained from the MATH assay (Table 2) showed that the cell surface hydrophobicity was dependent on carbon source. When B1 was grown on MSM supplied

Table 1 Oil displacement and emulsification activity ( $E_{24}$, with hexadecane and diesel oil respectively) of culture broth during growth of B1 and B2 in MSM containing different carbon sources

\begin{tabular}{cccc}
\hline \multirow{2}{*}{ Medium } & $\begin{array}{c}\text { Oil displacement } \\
\text { test }(\mathrm{cm})\end{array}$ & \multicolumn{2}{c}{$E_{24}(\%)$ (average $\left.\pm \mathrm{SD}\right)$} \\
\cline { 3 - 4 } & 10.2 & $60 \pm 3$ & $71 \pm 2$ \\
hexadecane & diesel oil \\
\hline B1 (0.2\% G) & 4.1 & $6.7 \pm 2$ & $8.0 \pm 4$ \\
B2 (0.5\% C16) & 3.2 & ND & $3.3 \pm 3$ \\
B1 $(0.2 \% \mathrm{G}+0.5 \% \mathrm{C} 16)$ & 4.5 & $18 \pm 4$ & $20 \pm 3$ \\
B2 $(0.2 \% \mathrm{G}+0.5 \% \mathrm{C} 16)$ & 3.8 & $6.3 \pm 3$ & $7.1 \pm 2$ \\
\hline
\end{tabular}

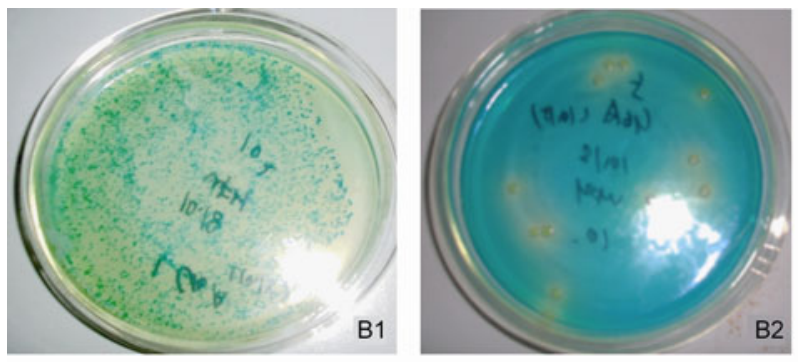

Figure 4 Blue agar culture analysis of B1 and B2.

Table 2 Effects of different carbon sources on hydrophobicity (microbial adherence to hydrocarbons or MATH) of hydrocarbon-degrading bacteria

\begin{tabular}{cc}
\hline Medium & MATH \\
\hline B1 $(0.5 \% \mathrm{C} 16)$ & 0.886 \\
B2 $(0.5 \% \mathrm{C} 16)$ & 0.852 \\
B1 $(0.2 \% \mathrm{G}+0.5 \% \mathrm{C} 16)$ & 0.739 \\
B2 $(0.2 \% \mathrm{G}+0.5 \% \mathrm{C} 16)$ & 0.713 \\
B1 $(0.2 \%$ glucose $)$ & 0.038 \\
\hline
\end{tabular}

$0.5 \% \mathrm{C} 16$ : The carbon source is $5,000 \mathrm{mg} / \mathrm{kg}$ hexadecane; $0.2 \%$ $\mathrm{G}+0.5 \% \mathrm{C} 16$ : the carbon source is $0.2 \%$ glucose and $5,000 \mathrm{mg} / \mathrm{kg}$ hexadecane; $0.2 \%$ Glucose: the carbon source is $0.2 \%$ glucose

with glucose, a dual carbon source (glucose and hexadecane) or hexadecane, the values of MATH were $0.04,0.74$, and 0.89 respectively. Because B2 could not grow on glucose, B2 was only tested in MSM containing hexadecane and the carbon source mixture. The values of MATH were 0.85 and 0.71 when B2 was grown on hexadecane and the carbon mixture respectively. Thus, when the substrate becomes more hydrophobic, cells are more likely to change their surface hydrophobicity to adapt to the new environmental conditions.

As shown in Figure 5, the cell hydrophobicity of B1 remained unchanged during its growth on glucose, and the value of MATH was maintained at about 0.04 . When cultured with hexadecane, cell hydrophobicity of B1 correlated with the age of the culture. B1 cells in the early or mid-exponential growth phase were less hydrophobic than cells in the stationary growth phase, while the value of MATH increased from 0.71 to 0.91 . However when B2 was grown on hexadecane, the cell hydrophobicity of B2 remained unchanged and the value of MATH was about 0.66 .

\subsection{Production and purification of biosurfactant}

Both B1 and B2 produced biosurfactants during their growth on hexadecane and on glucose according to the results of the oil displacement test, blue agar culture analysis, and cell surface hydrophobicity analysis. We carried out the extraction and purification of the biosurfactant. However, the biosurfactant could be extracted only when B1 was grown on MSM with glucose, and the extracted biosurfactant took on a brownish color. TLC analysis of the extracted 


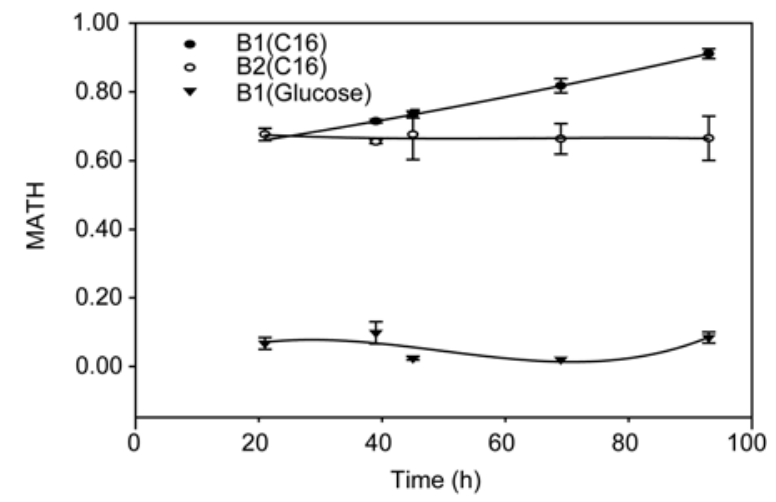

Figure 5 Difference of the cell-surface hydrophobicity of strains B1 and B2 during their growth.

biosurfactant from B1 indicated the presence of a glycolipid fraction, identified on the basis of yellow spots on the silica gel. Lipopeptides were undetectable in the extracted biosurfactant. Neither glycolipids nor lipopeptides were detected in the culture of $\mathrm{B} 2$.

\section{Discussion}

In this work, both B1 and B2 bacterial strains showed highly efficient degradation of hexadecane, albeit via different mechanisms. Depending on the state and size of the oil droplets relative to the size of microbial cells, two general types of hydrocarbon-cell interactions have been postulated: specific adhesion of cells to larger oil drops and pseudosolubilization involving cellular assimilation of emulsified small hydrocarbon droplets [11]. Goswami et al. [28] reported three mechanisms for the uptake of slightly soluble liquid hydrocarbon by microorganisms: (1) interaction of cells with hydrocarbon dissolved in the aqueous phase; (2) direct contact of cells with hydrocarbon drops considerably larger than the cells; (3) interaction of cells with "solubilized", "pseudosolubilized", "accommodated", "microemulisified", or "submicron" hydrocarbon droplets in entities much smaller than the cells. Therefore, different bacteria adopt different approaches when degrading hydrocarbon.

The isolated strain B1 was designated as Pseudomonas sp. B1. The ability of Pseudomonas aeruginosa to use hydrocarbons as an energy source has been demonstrated in several studies [18]. During the growth of B1 on n-hexadecane, a floating emulsion could be observed at the airmedium interface. These flocs of B1 were connected by an extracellular polymer, which was a complex mixture of glycoconjugates, suggesting the type of hydrocarbon-cell interaction taking place was specific adhesion of cells to larger oil drops. According to our results (Table 1), strain B1 grew well on hexadecane but showed a lower emulsifying activity than when grown on glucose, suggesting a link with the acid products generated in the culture medium. Belsky et al. [29] reported that the cleavage of fatty acids from emulsan decreased the emulsifying activity by more than $50 \%$. Milva et al. [30] suggested that glycolipids with regular long chain fatty acids presumably undergo lipid phase transition more readily, losing their emulsifying ability.

We found that B1 produced a glycolipid type of biosurfactant when grown on hexadecane or glucose. Pseudomonas is the best-known bacteria capable of using hydrocarbon as an energy source and producing biosurfactants [31-33]. Pseudomonas aeruginosa has been widely studied and is known to produce a glycolipid type of biosurfactant [34, 35]. Rhamnolipids are amphiphilic surface-active glycolipids that are usually secreted in the growth medium [36, 37], but can potentially be used to combat marine oil pollution [8]. Figure 5 shows that the value of MATH increased from 0.71 to 0.91 when B1 was cultured with hexadecane. It appears that biosurfactant-enhanced biodegradation is not simply a function of enhanced solubility, but is also due to changes induced in the cell surface [38]. For example, Zhang and Miller [18] found that rhamnolipids not only increased the apparent solubility of hydrocarbons, but also modified the cell surface resulting in greater hydrophobicity. Herman et al. [39] showed that the addition of rhamnolipids induced the formation of multicellular aggregates, implying that the cells forming these aggregates were hydrophobic in nature. These findings indicate that the intrinsic ability of a cell to interact with hydrocarbons in a growth medium increases significantly in the presence of rhamnolipids.

Table 2 illustrates how cell surface hydrophobicity changes when the carbon source is altered. When B1 was grown on MSM supplied with glucose, a dual carbon source (glucose and hexadecane) or hexadecane, the values of MATH were $0.04,0.74$, and 0.89 respectively. Some investigators have reported that changes in the carbon source can affect the cell wall, thus affecting cell surface hydrophobicity $[40,41]$. The surface hydrophobicity of some Pseudomonas bacteria has been shown to decrease when the bacteria are grown on carbon sources such as glucose and acetate $[42,43]$.

B2 was unable to use glucose as the sole source of carbon, similar to the findings with Acinetobacter RAG-1 isolated by Luo et al. [44]. Given that Acinetobacter RAG-1 lacks 6-phosphofructokinase, it may have been unable to harness the energy and primary metabolites from the glycolytic pathway [44]. When B2 grew on hexadecane, large oil drops were emulsified into small hexadecane droplets. This phenomenon suggests that the type of hydrocarbon-cell interaction taking place was pseudosolubilization, involving the cellular assimilation of emulsified small hydrocarbon droplets. This phenomenon was similarly reported by Reisfeld et al. for the RAG-1 strain [45]. RAG-1 produced emulsan, which was then absorbed onto the surface of the oil, effectively preventing the aggregation of oil droplets and forming a stable emulsion. This increased the opportunities for bacterial cells to make contact with alkanes, and 
subsequently enhanced the bacterial absorption of alkanes.

In general, biodegradation is accompanied by emulsification, resulting in a greater oil-water interface. Further evidence indicates that the greater the oil-water interface, the faster the rate of oil decomposition by microorganisms. During the growth of B2 on hexadecane, fatty acids were produced as evidenced by the decrease in $\mathrm{pH}$ (Figure 2). It has been postulated that fatty acids produced through alkane metabolism or triglyceride hydrolysis can aid the uptake of alkanes by emulsifying the substrate [46]. We also found that the B2 strain grown on hexadecane showed a low emulsifying activity, which correlates with the cleavage of fatty acids. One study reported that the cleavage of fatty acids from emulsan decreased the emulsifying activity by more than 50\% [29]. Like B1, when B2 grew on hexadecane, it also produced biosurfactants. Various gammaproteobacteria have the ability to produce biosurfactant molecules. For example, the Acinetobacter calcoaceticus RAG-1 can produce emulsan [47-54].

It is not clear why biosurfactants could not be extracted when strains B1 and B2 were grown on MSM with hexadecane. One of the reasons may be that the mechanisms responsible for biosurfactant excretion were controlled by the cells themselves, so that only necessary amounts of biosurfactant were produced when strains were growing on hexadecane. Although it has been possible to force microorganisms to overproduce biosurfactants such as rhamnolipids when cells have been cultivated on non-hydrophobic compounds like glycerol, such overproduction has never observed in the degradation of actual pollutants [50]. A further reason for the apparent lack of biosurfactant may be the decrease in $\mathrm{pH}$. One study found that surfactin (SF) produced by bacteria disappeared rapidly in the medium broth once the $\mathrm{pH}$ fell below 5.0 [51]. In a later study, the disappearance of SF was linked to its precipitation triggered by the accumulation of extracellular acidic metabolites [52].

In this study, biosurfactants were found to enhance both the solubility and the solubilization rate of hydrocarbons. Some researchers have reported that biodegradation rates of slightly soluble compounds increase significantly upon the introduction of biosurfactants to a reaction vessel [53]. Cell surface hydrophobicity has also been found to correlate with the degradability of organic pollutants in the environment. Strains with a greater cell surface hydrophobicity can degrade hydrophobic organic compounds faster than strains with a smaller cell surface hydrophobicity.

\section{Conclusions}

Two efficient hydrocarbon-biodegrading bacterial strains, B1 and B2, were isolated in soil from petroleum-contaminated sites in Tianjin, China, and identified as Pseudomonas aeruginosa and Acinetobacter junii, respectively. Both B1 and B2 were found to produce biosurfactants, but their modes of action were different, suggesting their mechanisms of biodegradation are different. Pseudosolubilization was behind the substrate degradation observed here, allowing uptake from hexadecane micelles by the hydrophilic cells of strain B1. Conversely, direct interfacial accession appeared to be the main mechanism for hexadecane uptake by B2. Our results show that different microbial strains employ different degradation mechanisms, where the role of biosurfactants is related to their surface properties. Thus, it may be necessary to fully investigate the modes of action of biosurfactants used in the bioremediation of contaminated land.

This work was supported by the National Natural Science Foundation of China (40901149, 81072989), the Foundation of the State Key Laboratory of Pollution Control and Resource Reuse Tongji University), China and the Chinese Universities Scientific Fund (ZD0904).

1 Lin TC, Young CC, Ho MJ, Yeh MS, Chou CL, Wei YH, Chang JS. Characterization of floating activity of indigenous diesel-assimilating bacterial isolates. J Biosci Bioeng, 2005, 99: 466-472

2 Liang YT, Nostrand JDV, Wang J, Zhang X, Zhou JZ, Li G. Microarray-based functional gene analysis of soil microbial communities during ozonation and biodegradation of crude oil. Chemosphere, 2009a, 75: 193-199

3 Liang YT, Zhang X, Dai DJ, Li GH. Porous biocarrier-enhanced biodegradation of crude oil contaminated soil. Int Biodeterior Biodegrad, 2009b, 63: 80-87

4 Thomassin LE, Eriksson M, Reimer K, Mohn W. Biostimulation and bioaugmentation for on-site treatment of weathered diesel fuel in Arctic soil. Appl Microbiol Biotechnol, 2002, 59: 551-556

5 Vinas M, Grifoll M, Sabate J, Solanas AM. Biodegradation of a crude oil by three microbial consortia of different origins and metabolic capabilities. J Ind Microbiol Biotechnol, 2002, 28: 252-260

6 Margesin R, Schinner F. Bioremediation (natural attenuation and biostimulation) of diesel-oil-contaminated soil in an Alpine glacier skiing area. Appl Microbiol Biotechnol, 2001, 67: 3127-3130

7 Bognolo G. Biosurfactants as emulsifying agents for hydrocarbons. Colloids Surf A, 1999, 152: 41-52

8 Rahman KSM, Banat IM, Thahira J. Bioremediation of gasoline-contaminated soil by a bacterial consortium amended with poultry litter, coir pith, and rhamnolipid biosurfactant. Bioresour Technol, 2002, 81: 25-27

9 Sei K, Mori K, Kohno T. Development and application of PCR for monitoring alkane-degrading bacteria in seawater microcosm during crude oil degradation process. J Chem Eng Jpn, 2003, 36: 1185-1193

10 Liu PWG, Whang LM, Yang MC, Cheng SS. Biodegradation of diesel-contaminated soil: A soil column study. J Chin Inst Chem Eng, 2008, 39: 419-428

11 Hommel RK. Formation and function of biosurfactants for degradation of water-insoluble substrates. Biochemistry of microbial biodegradation, pp, 1994, 63-87

12 Desai JD, Banat IM. Microbial production of surfactants and their commercial potential. Microbiol Mol Biol R, 1997, 61: 47-64

13 Rosenberg E, Ron EZ. High and low molecular mass microbial surfactants. Appl Microbiol Biotechnol, 1999, 52: 154-162

14 Mulligan CN, Yong RN, Gibbs BF. Surfactant-enhanced remediation of contaminated soil: a review. Eng Geol, 2001, 60: 371-380

15 Mata-Sandova JC, Karns J, Torrents A. Influence of rhamnolipids and Triton X-100 on the desorption of pesticides from soils. Environ Sci Technol, 2002, 36: 4669-4675

16 Urum K, Grigson S, Pekdemir T, McMenamy S. A comparison of the efficiency of different surfactants for removal of crude oil from contaminated soils. Chemosphere, 2006, 62: 1403-1410 
17 Komarov EV, Ganin PG. $\zeta$-Potential of n-alkane emulsion droplets and its role in substrate transport into yeast cells. Appl Biochem $\mathrm{Mi}$ crobiol, 2004, 40: 272-279

18 Zhang Y, Miller RM. Effect of a Pseudomonas rhamnolipid biosurfactant on cell hydrophobicity and biodegradation of octadecane. Appl Envir Microbiol, 1994, 60: 2101-2106

19 Chénier MR, Beaumier D, Roy R, Driscoll BT, Lawrence JR, Greer $\mathrm{CW}$. Impact of seasonal variations and nutrient inputs on nitrogen cycling and degradation of hexadecane by replicated river biofilms. Appl Envir Microbiol, 2003, 69: 5170-5177

20 Graham DW, Smith VH, Cleland DL, Law KP. Effects of nitrogen and phosphorous supply on hexadecane biodegradation in soil systems. Water, Air, Soil Pollut, 1999, 111: 1-18

21 Schoefs O, Perrier M, Samson R. Estimation of contaminant depletion in unsaturated soils using a reduced-order biodegradation model and carbon dioxide measurement. Appl Microbiol Biotechnol, 2004, 64: 53-61

22 Rodrigues LR, Teixeira JA, Mei HC, Oliveira R. Physicochemical and functional characterization of a biosurfactant produced by Lactococcus lactis 53. Colloids Surf B, 2006, 49: 79-86

23 Pornsunthorntaweea O, Wongpanita P, Chavadeja S, Abeb M, Rujiravanit $R$. Structural and physicochemical characterization of crude biosurfactant produced by Pseudomonas aeruginosa SP4 isolated from petroleum-contaminated soil. Bioresour. Technol, 2008, 99: $1589-1595$

24 Cooper DG, Goldenberg BG. Surface-active agents from two Bacillus species. Appl Envir Microbiol, 1987, 53: 224-229

25 Siegmund I, Wagner F. New method for detecting rhamnolipids excreted by Pseudomonas species during growth on mineral agar. Biotechnol Tech, 1991, 5: 265-268

26 Rahman KSM, Rahman TJ, Kourkoutas Y, Petsas I, Marchant R, Banat IM. Enhanced bioremediation of $n$-alkane in petroleum sludge using bacterial consortium amended with rhamnolipid and micronutrients. Bioresour Technol, 2003, 90: 159-168

27 Jiraporn T, Tanusta C, Polakit S. Production of sophorolipid biosurfactant by Pichia anomala. Biosci Biotechnol Biochem, 2008, 72: 2061-2068

28 Goswami P, Singh HD. Different modes of hydrocarbon uptake by two Pseudomonas species. Biotechnol Bioeng, 1992, 37: 1-11

29 Belsky I, Gutnick DL, Rosenberg E. Emulsifier of Arthrobacter RAG-1: determination of emulsifier-bound fatty acids. FEBS Lett, 1979, 101: 175-178

30 Milva P, Attilio C, Gianfranco L, Franco B. An Antarctic psychrotrophic bacterium Halomonas sp. ANT-3, growing on n-hexadecane, produces a new emulsifying glycolipid. FEMS Microbiol Ecol, 2005, 53: 157-166

31 Beal R, Betts WB. Role of rhamnolipid biosurfactants in the uptake and mineralization of hexadecane by hydrocarbon assimilation and biosurfactant producing Pseudomonas aeruginosa. J Appl Microbiol, 2000, 89: 158-168

32 Noordman WH, Janssen DB. Rhamnolipid stimulates uptake of hydrophobic compounds by Pseudomonas aeruginosa. Appl Envir Microbiol, 2002, 68: 4502-4508

33 Rahman KSM, Rahman TJ, McClean S, Marchant R, Banat IM. Rhamnolipid biosurfactant production by strains of Pseudomonas aeruginosa using low-cost raw materials. Biotechnol Progr, 2002, 18: 1277-1281

34 Ochsner UA, Hembach T, Fiechter A. Production of rhamnolipid biosurfactants. Adv Biochem Eng Biotechnol, 1996, 53: 89-118

35 Lang S, Wullbrandt D. Rhamnose lipids biosynthesis, microbial pro- duction and application potential. Appl Microbiol Biotechnol, 1999, 51: 22-32

36 Ellaiah P, Prabhakar T, Sreekanth M, Taleb AT, Raju PB, Saisha V. Production of glycolipids containing biosurfactant by Pseudomonas species. Indian J Exp Biol, 2002, 40: 1083-1086

37 Tuleva BK, Ivanov GR, Christova NE. Biosurfactant production by a new Pseudomonas putida strain. Z Naturforschung C, 2002, 57: 356360

38 Zinjarde SS, Pant A. Emulsifier from a tropical marine yeast, Yarrowia lipolytica NCIM 2589. J Basic Microbiol, 2002, 42: 67-73

39 Herman DC, Zhang Y, Miller RM. Rhamnolipid (biosurfactant) effects on cell aggregation and biodegradation of residual hexadecane under saturated flow conditions. Appl Envir Microbiol, 1997, 58: 3276-3282

40 Kirobe T, Hansen JLS. Phytoplankton aggregate formation observation of patterns and mechanisms of cell sticking and the significance of exopolymeric material. J Plankton Res, 1993, 15: 993-1018

41 Zhao Q, Zhang JY, Chen LZ, Zheng JX, Zhao L, Yin HM. Cellsurface hydrophobicity and degradation characteristics of hydrophobic hydrocarbon degrading bacteria. Environ Sci, 2005, 26: 132-135

42 Al-Tahhan RA, Sandrin TR, Bodour AA, Maier RM. Rhamnolipid induced removal of lipopolysaccharide from Pseudomonas aeruginosa: effect on cell surface properties and interaction with hydrophobic substrates. Appl Envir Microbiol, 2000, 66: 3262-3268

43 Prabhu Y, Phale PS. Biodegradation of phenanthrene by Pseudomonas sp. strain PP2: novel metabolic pathway role of biosurfactant and cell surface hydrophobicity in hydrocarbon assimilation. Appl Microb Biotech, 2003, 6: 342-351

44 Luo Q, Pu WF, Teng XL, Luo M, Zhao JQ. Progress in high-molecular-weight biosurfactnat emulsan. China Surfactant Detergent and Cosmetics, 2008, 38: 185-188

45 Reisfeld A, Rosenberg E, Gutnick D. Microbial degradation of crude oil-factors affecting the dispersion in sea water by mixed and pure cultures. J Appl Microb, 1972, 24: 363-368

46 Breuil C, Kushner DJ. Effects of lipids, fatty acids and other detergents on bacterial utilization of hexadecane. Can J Microbiol, 1980, 26: 223-231

47 Gorkovenko A, Zhang J, Gross RA, Allen AL, Kaplan DL. Bioengineering of emulsifier structure: emulsan analogs. Can J Microbiol, 1997, 43: 384-390

48 Zhang J, Gorkovenko A, Gross RA, Allen AL, Kaplan D. Incorporation of 2-hydroxyl fatty acids by Acinetobacter calcoaceticus RAG-1 to tailor emulsan structure. Int J Biol Macromol, 1997, 20: 9-21

49 Gorkovenko A, Zhang J, Gross RA, Kaplan DL. Control of unsaturated fatty acid substitutes in emulsans. Carbohydr Polym, 1999, 39: 79-84

50 Chrzanowski L, Owsianiak M, Szulc A, Olszanowski A. Adsorption of sodium dodecyobenzenesulphonate (SDBS) on Candida maltose EH 15 strain: influence on cell surface hydrophobicity and n-alkanes biodegradation. Water, Air, Soil Pollut, 2009, 196: 345-353

51 Whang LM, Liu PWG, Ma CC, Cheng SS. Application of rhamnolipid and surfactin for enhanced diesel biodegradation - effects of $\mathrm{pH}$ and ammonium addition. J Hazard Mater, 2009, 164: 1045-1050

52 Wei YH, Wang LF, Changy JS, Kung SS. Identification of induced acidification in iron-enriched cultures of Bacillus subtilis during biosurfactant fermentation. J Biosci Bioeng, 2003, 96: 174-178

53 Zhang Y, Miller RM. Enhanced octadecane dispersion and biodegradation by a Pseudomonas rhamnolipid surfactant (biosurfactant). Appl Envir Microbiol, 1992, 58: 3276-3282 